\title{
KEMAMPUAN MENGHAFAL AL-QUR'AN DENGAN METODE KAISA DALAM PERSPEKTIF MULTIPLE INTELLIGENCE
}

\author{
${ }^{1}$ Umi Salamah \\ STAI Ma'had Aly Al-Hikam Malang \\ email: umisalamah393@gmail.com
}

\begin{abstract}
Technological developments bring a lot of impact to the community without the exception of children, from gadgets, games, music, movies, and so on. This makes children reluctant to learn the science of religion, especially the Qur'an. Al-Qur'an as a way of life for Muslims, must be studied, and applied in life. The purpose of this study is to determine the ability to memorize the Qur'an using the Kaisa method in the perspective of multiple intelligence. The Kaisa method is a way of memorizing the Koran which is oriented to memorization and understanding of the verses of the Koran along with their meanings through movements or kinesthetic which are adapted to the meaning of each verse so as to make it easy to understand and remember every verse of the Qur'an given. This research was conducted at RTQ Malang City. This research method is descriptive qualitative, data collection is through observation, interviews, and documentation. The results of the study found that memorizing the Qur'an using the Kaisa method was able to increase the interest of children in memorizing the Qur'an, understanding the meaning, and accommodating multiple intelligences (multiple intelligence)
\end{abstract}

\section{Keywords: Memorizing the Qur'an; The Kaisa Method; Multiple Intelligence}

\begin{abstract}
Abstrak: Perkembangan teknologi membawa banyak dampak terhadap masyarakat tanpa terkecuali anak-anak, mulai gadget, game, musik, film, dan sebagainya. Hal ini menjadikan anak enggan untuk mempelajari ilmu agama terutama Al-Qur'an. Al-Qur'an sebagai pedoman hidup bagi umat Islam, wajib untuk dipelajari, dan diterapkan dalam kehidupan. Tujuan penelitian ini untuk mengetahui kemampuan menghafal Al-Qur'an menggunakan metode kaisa dalam perspektif multiple intelligence. Metode kaisa adalah cara menghafal al-Qur'an yang berorientasi pada hafalan dan pemahaman ayat al-Qur'an beserta artinya melalui gerakan atau kinestetik yang disesuaikan dengan arti setiap ayat sehingga memberikan kemudahan untuk memahami dan mengingat setiap ayat Al-Qur'an yang diberikan. Penelitian ini dilaksanakan di RTQ Kota Malang. Metode penelitian ini adalah deskriptif kualitatif, pengumpulan datanya melalui observasi, wawancara, dan dokumentasi. Hasil penelitian diperoleh bahwa menghafal Al-Qur'an menggunakan metode Kaisa mampu meningkatkan minat anak dalam menghafal Al-Qur'an, memahami makna, dan mengakomodir beberapa kecerdasan (multiple intelligence)
\end{abstract}

Kata Kunci: Menghafal Al Qur'an; Metode Kaisa, Multiple Intelligence

\section{A. PENDAHULUAN}

Peer reviewed under reponsibility of STIT ISLAMIC VILLAGE.

(C) 2018 STIT ISLAMIC VILLAGE, All right reserved, This is an open access article under 86 the CC BY SA license (https://creativecommons.org/licenses/by-sa/4.0/) 
Homepage: http://e-journal.stit-islamic-village.ac.id/index.php/istighna

Umi Salamah

Kemampuan Menghafal Al-Qur'an Dengan Metode Kaisa Dalam Perspektif Multiple Intelligence

Agama Islam adalah wahyu yang diturunkan oleh Allah SWT kepada RasulNya untuk disampaikan kepada segenap umat manusia dimana saja dan sepanjang masa yang mengatur segala peri kehidupan dan penghidupan manusia dalam berbagai hubungan, baik hubungan manusia dengan Tuhannya, hubungan manusia dengan sesama manusia, maupun hubungan manusia dengan alam. Bersumber pada kitab suci Al-Qur'an sebagai penyempurna wahyu-wahyu Allah sebelumya, sejak manusia dihadirkan di bumi, yang dilengkapi dan dijelaskan oleh Sunnah Rasulullah SAW. ${ }^{1}$

Al-Qur'an sebagai pedoman hidup dan wajib bagi umat Islam untuk mempelajari dan menerapkannya dalam kehidupan. Begitu pentingnya untuk mempelajari Al-Qur'an, ayat pertama yang diturunkan berbunyi iqro' (bacalah). Jika diartikan secara mendalam, ayat ini adalah perintah untuk tidak hanya sekedar perintah membaca, tapi benar-benar tercermin dalam pikiran, perkataan, dan perbuatan.

Pada hakikatnya metode pembelajaran Al- Qur'an dilakukan dengan cara verbal dengan mengoptimalkan tiga tahapan dalam proses belajarnya (pendengaran, penglihatan, dan hati (pemaknaan)). Sebagaimana peritiwa dibelajarkannya kata Iqra ${ }^{e e}$ oleh Malaikat Jibril kepada Nabi Muhammad Saw. ${ }^{2}$

Memperkenalkan Al-Qur'an sejak dini akan lebih cepat melekat dan tidak mudah hilang. Karena pada usia anak-anak, kemampuan otak untuk menyerap informasi masih sangat baik. Akan sangat baik jika anak-anak lebih dulu dikenalkan dengan Al-Qur'an sebelum pengetahuan yang lainnya.

Menumbuhkan rasa cinta terhadap Al-Qur'an tidak dapat dilakukan secara instan dan dalam waktu singkat, dibutuhkan proses untuk mengenal kemudian ingin mempelajari dan menerapkannya dalam kehidupan. Agar menumbuhkan rasa ingin tahu dalam mempelajari Al-Qur'an, dibutuhkan rasa cinta atau ketertarikan untuk mempelajarinya. Salah satu wujud cinta terhadap Al-Qur'an adalah dengan menghafalkan dan memahami maknanya serta menjaga hafalannya.

Menghafal Al-Qur'an tidak semudah membalik telapak tangan, tidak juga hanya dengan wacana, tetapi dibutuhkan ikhtiyar dan niat yang kuat. Mendekatkan anak sedini mungkin dengan Al-Qur'an, dengan cara yang anak sukai dan minati. Orang tua sebagai penentu arah, madrasah pertama, dan figur bagi sang anak harus mampu menciptakan atmosfir yang sangat dekat dengan Al-Qur'an.

Dewasa ini kesadaran orang tua untuk membekali anak tentang agama terutama dalam mengahafal Al-Qur'an membuat banyak instansi pendidikan yang menyambut baik niat ini. Banyak madrasah/sekolah, madrasah diniyah yang menjadikan program hafalan sebagai program unggulan. Banyak metodemetode yang diterapkan agar proses menghafal bisa cepat dan mudah.

\footnotetext{
${ }^{1}$ Mudzakir A, Pengantar Studi Islam, (Semarang: Wahid Hasyim University Press, 2014), hlm. 82

${ }^{2}$ Eko Setiawan, 'Meningkatkan Kemampuan Membaca Awal Al-Qur'an Melalui Metode Albana Pada Anak Usia 5-6 Tahun', AL-MUDARRIS: Journal of Education, 1.45 (2018), 68-75 <https://doi.org/10.32478/al-mudarris.v1i2.170>.
} 
Homepage: http://e-journal.stit-islamic-village.ac.id/index.php/istighna

Umi Salamah

Kemampuan Menghafal Al-Qur'an Dengan Metode Kaisa Dalam Perspektif Multiple Intelligence

Beberapa metode yang ditawarkan antara lain Tabarok, Al-Bana, Hanifida, Al-Barqy, metode drill, dan lain sebagainya. Tujuan diterapkannya metodemetode tersebut adalah untuk mempermudah proses menghafal Al-Qur'an. Dan setiap metode pasti memiliki kekurangan dan kelebihannya masingmasing.

Usia anak-anak rentang konsentrasinya masih pendek, anak akan bosan jika diminta duduk diam dan mendengarkan. Selain mendengarkan, anak-anak juga membutuhkan visual dan gerak agar mudah untuk mempelajari dan memahami sesuatu. Hal ini juga dapat diterapkan dalam menghafal Al-Qur'an.

Mengajarkan hafalan Al-Qur'an pada anak memang baik, tapi alangkah baiknya jika tetap memperhatikan perkembangan anak. Dunia anak-anak adalah dunia bermain, kita tidak boleh menghilangkan fitrah tersebut. Sehingga aktifitasnya harus disesuaikan dengan kebutuhan dan karakteristik anak.

Metode kaisa sesuai diterapkan dalam menghafal Al-Qur'an pada anak. Metode ini memadukan antara melafalkan dengan benar, gerakan, dan arti. Sehingga dalam satu kegiatan sudah mengkombinasikan beberapa aspek kecerdasan/multiple intelegence. Dengan gerakan anak menjadi antusias untuk mempelajari dan menghafal Al-Qur'an, setiap gerakan sesuai dengan arti dari ayat yang dibacakan.

Beberapa penelitian terdahulu yang membahas tentang metode kaisa diantaranya Pengajaran Menggunakan Metode Kaisa dalam Menghafal Al Quran pada Anak, yang menjelaskan tentang pengertian metode kaisa, langkah-langkah dalam pembelajarannya, serta kelebihan dan kelemahan metode kaisa. ${ }^{3}$

Studi Perbandingan Kemampuan Menghafal Al- Qur'an dengan Metode Kaisa dan Metode Wafa Dalam Menghafal Al-Qur'an pada Anak Usia Dasar di Rumah Tadabbur Qur'an (RTQ) Kendari ${ }^{4}$. Penelitian ini adalah untuk mengetahui perbedaan kemampuan menghafal anak Qur'an (chilhood tengah) di Rumah Tadabbur Qur an (RTQ) Hombis di kota Kendari baik sebelum dan sesudah metode kaisa dan metode wafa diterapkan. Penelitian ini menggunakan metode penelitian kuantitatif dengan pendekatan eksperimental. Hasil penelitian ini diperoleh bahwa ada perbedaan positif dan signifikan dalam kemampuan menghafal Al Qur'an sebelum dan sesudah diberi perlakuan metode Kaisa. Hal ini dibuktikan dengan nilai signifikansi $0,000<\alpha=0,05$ sehingga H0 ditolak (3) Ada perbedaan positif dan signifikan dalam kemampuan menghafal Al Qur'an sebelum dan sesudah diberikan pengobatan metode Wafa. Ini dibuktikan dengan nilai signifikansi $0,000<\alpha=0,05$ sehingga H0 ditolak (4) Ada perbedaan positif dan signifikan dalam kemampuan menghafal Al-Qur'an setelah diperlakukan dengan metode Kaisa

\footnotetext{
${ }^{3}$ Umi Salamah, 'Pengajaran Menggunakan Metode Kaisa Dalam Menghafal Al-Qur'an Pada Anak', TA'LIMUNA, 7.2 (2018), 124-28.

${ }^{4}$ Maryam Kharis Sulaiman, Hasri, 'Studi Perbandingan Kemampuan Menghafal AlQur'an Dengan Metode Kaisa Dan Metode Wafa Dalam Menghafal Al-Qur'anpada Anak Usia Dasar Di Rumah Tadabbur Qur'an (Rtq) Kendari', Tadarus: Jurnal Pendidikan Islam, 8.1 (2019).
} 
Homepage: http://e-journal.stit-islamic-village.ac.id/index.php/istighna

Umi Salamah

Kemampuan Menghafal Al-Qur'an Dengan Metode Kaisa Dalam Perspektif Multiple Intelligence

dan metode Wafa. Ini dibuktikan dengan nilai signifikansi $0,02<\alpha=0,05$ sehingga $\mathrm{H} 0$ ditolak.

Berbeda dengan penelitian sebelumnya, penelitian ini fokus pada kemampuan menghafal Al-Qur'an dengan metode dalam perspektif multiple intelligence.

\section{B. METODE PENELITIAN}

Penelitian ini berjenis kualitatif dengan pendekatan studi kasus. Pedalaman kasus dilakukan untuk mengetahui kemampuan menghafal Alqur'an dengan metode kaisa dalam perspektif multiple intelligence. Tempat penelitian dilakukan di RTQ Dinoyo Kota Malang. Data penelitian meliputi; penerapan metode kaisa dalam menghafal Al-Qur'an dan hubungannya dengan multiple intelligence. Subjeknya dalam penelitian ini adalah guru dan anak RTQ Dinoyo Kota Malang. Data dikumpulkan dengan teknik wawancara mendalam, dokumentasi dan observasi.

\section{PEMBAHASAN DAN HASIL PENELITIAN}

\section{Metode Kaisa dalam Menghafal Al-Qur'an}

Metode adalah cara kerja yang bersistem untuk memudahkan pelaksanaan suatu kegiatan guna mencapai tujuan yang ditentukan. ${ }^{5}$ Berdasarkan pengertian tersebut dapat diartikan bahwa metode adalah cara yang digunakan untuk mencapai tujuan. Jadi, metode yang digunakan harus sesuai dengan tujuan yang akan dicapai.

Menghafal Al-Qur'an merupakan proses yang tidak mudah dan harus terus berkesinambungan. Mengajarkan menghafal Al-Qur'an dibutuhkan metode yang tepat agar anak mudah menghafal dan tertarik untuk mempelajarinya. Salah satu metode yang sesuai untuk anak dalam menghafal Al-Qur'an adalah metode kaisa.

Metode Kaisa adalah cara menghafal al-Qur'an yang berorientasi pada hafalan dan pemahaman ayat al-Qur'an beserta artinya melalui gerakan atau kinestetik yang disesuaikan dengan arti tiap ayat sehingga memberikan kemudahan bagi anak untuk memahami dan mengingat setiap ayat alQur'an yang diberikan. Metode Kaisa adalah salah satu dari sekian banyak metode dalam menghafal al-Qur'an, namun kekuatan metode Kaisa terletak pada pendekatan agar anak menjadi rileks saat menghafal, dan tetap mengutamakan tajwid. ${ }^{6}$

Metode ini sesuai untuk anak karena rentang konsentrasi anak masih relatif pendek, dengan gerakan anak tidak harus duduk diam mendengarkan tetapi sambil bergerak sesuai dengan arti ayat yang dibacakan. Hal ini juga menambah perbendaharaan kata dan gerak anak. Ada beberapa kecerdasan yang diasah dalam metode kaisa, kecerdasan linguistik, kecerdasan

\footnotetext{
${ }^{5}$ https://kbbi.kemdikbud.go.id/entri/metode. diakses pada 5 Juli 2019

${ }^{6}$ Bersama Islam, Lima bersaudara Ini Hafal Quran dengan Metode Unik, www.bersamaislam.com/2016/04/lima-bersaudara-ini-hafal-quran-dengan.html?m=1 diakses pada 5 Juli 2019
} 
Homepage: http://e-journal.stit-islamic-village.ac.id/index.php/istighna

Umi Salamah

Kemampuan Menghafal Al-Qur'an Dengan Metode Kaisa Dalam Perspektif Multiple Intelligence

kinestetik, kecerdasan audio visual, dan kecerdasan inter personal. Metode ini sesuai untuk anak kinestetik, yang gaya belajarnya lebih menyukai aktifitas fisik, melatih anak intra personal untuk bersosialisasi, dan membantu anak audio visual untuk lebih mudah menghafal karena belajar dengan mendengar sekaligus melihat. Kaisa: ${ }^{7}$

Berikut langkah-langkah pembelajaran menghafal dengan metode

a. Guru memberi salam

b. Menyiapkan atau memberi aba-aba kepada anak persiapan proses belajar mengajar.

c. Presensi kehadiran anak

d. Membaca basmalah dan do'a sebelum belajar

e. Muroja'ah atau mengulang hafalan

f. Tambahan hafalan dengan membaca ayat perkata dengan gerakan/kinestetik

g. Menjelaskan hukum tajwid serta maknanya/tafsirnya

h. Anak melafalkan ayat secara berulang-ulang sampai ayat tersebut dihafal

i. Satu per satu anak melafalkan ayat sesuai hukum tajwidnya dan menerjemahkan per kata

j. Guru menyimak hafalan ayat yang dihafalkan oleh masing-masing anak

k. Guru membenarkan jika ada kesalahan dengan hukum tajwid serta artinya

1. Setelah ayat pertama dihafal, guru membimbing anak untuk lanjut ke ayat berikutnya dengan perlakuan yang sama

m. Merefleksi pembelajaran dengan memberi game sambung ayat (yaitu hafalan surat-surat secara berkesinambungan)

n. Menutup pembelajaran dengan do'a senandung al-Qur'an dan do'a kafaratul majelis secara berjama'ah.

Mengkombinasikan otak kanan dan kiri memang tidak mudah, akan tetapi ini menarik untuk anak. Di masa golden age anak, yang daya serapnya sangat baik dan rasa ingin tahu yang tinggi membuat penerapan metode ini efektif. Anak tidak harus duduk manis mendengarkan murotal dan mengulang-ngulang bacaan/dril. Kegiatan pembelajarannya dengan gerakan, bermain, kuis, dan diberi kesempatan satu-satu untuk mempraktikkan. Gerakan sesuai dengan artinya, sehingga anak tahu arti setiap ayat. Misalnya, kata syaithon maka kedua tangan di atas kepala sambil mengacungkan dua jari telunjuknya artinya setan. Kata Arrahman (Maha Pengasih), kedua tangan disilangkan di dada, kata Arrahiim (Maha Penyayang), kedua tangan diletakkan di bawah dagu, seperti menyangga dagu. Ketika anak lupa bacaannya, bisa memanggil memori anak hanya dengan isyarat gerakan.

\section{Kelebihan dan kelemahan Metode Kaisa}

Kelebihan metode kaisa:

${ }^{7}$ http://digilib.iainkendari.ac.id/786/3/BAB\%20II.pdf diakses 5 Juli 2019 

a. Menarik untuk anak karena menggunakan gerakan
b. Memperkaya perbendaharaan kata dan gerakan pada anak
c. Mengkombinasikan beberapa kecerdasan
d. Melatih otak kanan dan kiri
e. Anak tidak hanya menghafal tapi juga memahami tajwid dan artinya Kelemahan metode kaisa:
a. Proses menghafal membutuhkan waktu lebih lama
b. Membutuhkan keterampilan khusus guru
c. Membutuhkan perencanaan yang matang

\section{Penerapan Metode Kaisa di RTQ Dinoyo Kota Malang}

RTQ yang terletak di Jl. Bendungan Bening Kota Malang ini sudah mulai aktif sejak tahun 2017 dengan jumlah anak 9 anak yang rentang usianya antara 3-8 tahun. Sebelum mengikuti kegiatan di RTQ, seluruh wali anak diminta untuk menandatangi surat kesepakatan yang isinya tentang komitmen untuk mendampingi putra-putrinya istiqomah dalam menghafal Al-Qur'an dan bersedia mengikuti tata tertib yang ada di RTQ. Jadwal masuk setiap hari Senin sampai Kamis, dari pukul 15.30-17.00. setiap anak wajib membawa bekal sendiri dan dilarang membawa mainan.

Pembelajaran diawali dengan salam, doa sebelum belajar, presensi, dan proses pembelajaran dengan menggunakan metode kaisa. Untuk menghafal surat baru, awalnya gurunya membaca per-ayat dengan gerakannya dan diulangi beberapa kali. Kemudian anak bersama-sama menirukan sambil dibimbing guru. Selanjutnya anak diminta mempraktikkan satu persatu.

Setelah semua anak bisa mempraktikkan bacaan dan gerakan satu ayat, selanjutnya guru membaca arti dan gerakan ayat tersebut. Anak diminta mengulangi secara bersama-sama, kemudian mempraktikan satu persatu. Hal itu dilakukan berulang-ulang sampai satu surat selesai, jika suratnya panjang bisa dibagi beberapa hari. Setiap surat dijelaskan asbabun nuzulnya, kisah-kisah di dalamnya, dan pesan moral yang dapat diambil. Disela-sela menghafal, anak juga diajari menggambar, mewarna, melipat, dll.

Setiap akhir pembelajaran guru menulis di buku perkembangan setiap anak yang berisi beberapa tabel, surat apa yang dihafal hari ini, menghafalnya sudah baik atau belum, datangnya tepat waktu atau tidak, dan membawa bekal atau tidak. Di kolom bawah sendiri tentang deskripsi dari guru untuk masing-masing anak. Guru memberi reward jika anak bisa menghafal dengan baik, dan belajar dengan tertib. Reward kadang berupa permen, kue, atau asesoris lainnya. Dan setiap hari kamis, anak setoran hafalan yang sudah dihafal dalam minggu tersebut. Dalam empat hari anak mampu menghafal 1 surat beserta gerakan dan artinya.

Untuk menumbuhkan semangat, setiap beberapa bulan sekali diadakan lomba menghafal di dalam RTQ. Hadiahnya berupa alat tulis, kue, dan mainan. Dengan diadakan lomba tersebut, anak jadi termotivasi untuk terus murojaah dan istiqomah menghafal Al-Qur'an.

\section{Pembelajaran Metode Kaisa dalam Perspektif Multiple Intelligences}


Gardner mengklasifikasikan ada delapan macam kecerdasan (Garddner's Multiple Intelligences), yaitu kecerdasan logika matematik, kecerdasan bahasa/verbal, kecerdasan spasial/visual, kecerdasan kinestetik, kecerdasan kecerdasan musical/ritmik, kecerdasan interpersenol, kecerdasan intrapersonal, dan kecerdasan natural.

a. Kecerdasan logika matematik

Bentuk kecerdasan ini termasuk yang paling mudah distandarisasikan dan diukur. Kecerdasan ini sebagai pikiran analitik dan sainstifik, dan bisa melihatnya dalam ahli-ahli sains, programmer computer, akuntan, banker, dan tentu saja ahli matematik.

b. Kecerdasan bahasa/linguistik

Bentuk kecerdasan ini ditampakkan oleh kepekaan akan makna dan urutan kata serta kemampuan membuat beragam penggunaan bahasa untuk menyatakan dan memaknai arti yang komplek.

c. Kecerdasan spasial/visual

Bentuk kecerdasan ini umumnya terampil menghasilkan imajinasi mental dan menciptkan representasi grafis, mereka sanggup berpikir tiga dimensi, mampu mencipta ulang dunia visual. Kecerdasan ini dapat ditemukan pada pelukis, pematung, programmer computer, desainer, arsitek.

d. Kecerdasan Kinestetik

Bentuk kecerdasan ini memungkinkan terjadinya hubungan antara pikiran dan tubuh yang diperlukan untuk berhasil dalam aktifitasaktifitas seperti menari, berolah raga, seni bela diri, bermain teater.

e. Kecerdasan musikal

Bentuk kecerdasan ini mendengarkan pola music dan ritmik secara natural dan kemudian dapat memproduksinya. Bentuk kecerdasan ini sangat menyenangkan, karena music memiliki kapasitas untuk mengubah kesadaran kita, menghilangkan stress dan meningkatkan fungsi otak.

f. Kecerdasan interpersonal

Bentuk kecerdasan ini biasanya mereka yang pintar membaca suasana hati, temperamen, motivasi dan maksud orang lain. Mereka dengan kecerdasan ini memiliki kemampuan negosiasi dan menyediakan umpan balik atau evaluasi.

g. Kecerdasan intrapersonal

Bentuk kecerdasan ini merupakan kemampuan untuk memahami dan mengartikulasikan cara kerja terdalam dari karakter dan kepribadian.

h. Kecerdasan natural

Bentuk kecerdasan ini dapat dipandang sebagai sebuah komponen "nilai" yang ditambahkan padanya. Kecerdasan natural merupakan kecerdasan yang menuntun diri kita menjadi manusia yang utuh, mampu menyesuaikan diri dengan alam.

Metode kaisa ini sangat menarik untuk anak-anak, karena metode ini menggabungkan antara verbal, matematik logik, linguistik, kinestetik, visual, intra personal, dan sebagainya. Dengan metode ini anak dapat 
Kemampuan Menghafal Al-Qur'an Dengan Metode Kaisa Dalam Perspektif Multiple Intelligence

menghafal sekaligus memahami artinya, tanpa mengesampingkan makharijul huruf dan tajwidnya. Di sela-sela menghafal juga dijelaskan asbabun nuzul surat yang dihafalkan tersebut diturunkan. Anak-anak dapat menghafal, menambah perbendaharaan kata dan gerakan, serta manambah pengetahuan tentang sebab diturunkannya surat dalam Al-Qur'an.

Secara spesifik metode kaisa dikaji dalam perspektif mulitiple intelligence dijelaskan pada tabel. 1

Tabel.C.1. Metode Kaisa dalam Multiple Intelligences

\begin{tabular}{|c|c|c|c|}
\hline No. & Unsur kegiatan & Bentuk kegiatan & Kecerdasan \\
\hline 1. & Pembelajaran & $\begin{array}{l}\text { Klasikal } \\
\text { Privat }\end{array}$ & $\begin{array}{l}\text { Interpersonal } \\
\text { Intrapersonal }\end{array}$ \\
\hline \multirow[t]{6}{*}{2.} & $\begin{array}{l}\text { Metode } \\
\text { Pembelajaran }\end{array}$ & $\begin{array}{l}\text { Demontrasi } \\
\text { Menunjukkan ayat dengan jari }\end{array}$ & $\begin{array}{l}\text { Kinestetik } \\
\text { Matematik logik }\end{array}$ \\
\hline & & $\begin{array}{l}\text { Menjelaskan gerakan dengan } \\
\text { artinya }\end{array}$ & Linguistik \\
\hline & & Memberi contoh gerakan & $\begin{array}{l}\text { Visual dan } \\
\text { kinestetik }\end{array}$ \\
\hline & & $\begin{array}{l}\text { Waktu istirahat didengarkan } \\
\text { murotal }\end{array}$ & Musikal \\
\hline & & $\begin{array}{l}\text { Anak diajak belajar di luar } \\
\text { ruangan agar tidak bosan }\end{array}$ & Natural \\
\hline & & $\begin{array}{l}\text { Buku } \\
\text { penghubung/perkembangan }\end{array}$ & Matematik logik \\
\hline
\end{tabular}

Metode kaisa merupakan metode yang memfasilitasi semua kecerdasan. Ketika pembelajaran klasikal, membuat anak yang interpersonal merasa nyaman karena bisa berinteraksi dengan temantemannya. Begitu juga anak intrapersonal bisa berlatih untuk bersosialisasi dengan temannya. Saat pembelajaran privat, anak intrapersonal bisa belajar dengan nyaman. Setiap mengajarkan kosa kata baru, guru mendemonstrasikan (kecerdasan kinestetik) setiap gerakan sekaligus mengucapkan lafad dan artinya (linguistik), ini dilakukan berkali-kali sampai anak-anak mampu menirukan (visual). Anak yang suka bergerak (kinestetik) jadi sangat antusis karena saat menghafal sambil bergerak, tidak harus duduk diam mendengarkan. Dan dari hasil penelitian dari beberapa anak kinestetik, diketahui bahwa meski sambil bergerak, mereka mampu mengikuti dengan baik.

Setelah diberi contoh, anak menirukan secara bersama-sama, setiap anak diberi kesempatan mencoba satu persatu. Hal ini melatih keberanian anak, dan untuk mengukur kemampuan anak. Guru menyebutkan ada berapa ayat dan menunjuk dengan jari ayat keberapa yang sedang dibaca, ini merupakan kecerdasan matematik logik. Disela-sela istirahat anak-anak didengarkan murotal (musikal), dan sesekali anak-anak diajak belajar di luar/alam terbuka agar tidak bosan (natural). Setelah selesai pembelajaran, guru menuliskan di buku penghubung tentang surat dan ayat berapa yang 
ISTIGHNA, Vol. 2, No 2, Juli 2019 P-ISSN 1979-2824

Homepage: http://e-journal.stit-islamic-village.ac.id/index.php/istighna

Umi Salamah

Kemampuan Menghafal Al-Qur'an Dengan Metode Kaisa Dalam Perspektif Multiple Intelligence

difalkan hari itu, kemudian memberikan catatan tentang perkembangan anak.

\section{KESIMPULAN}

Berdasarkan pembahasan di atas, dapat disimpulkan bahwa Metode Kaisa dalam menghafal Al-Qur'an ditinjau dari perspektif multiple intelligences ( 8 kecerdasan) sudah diinternalisasikan dengan baik. Metode kaisa sudah menerapkan sistem dan metode pembelajaran al Qur'an berbasis multiple intelligences. Meskipun dalam prosesnya memakan waktu cukup lama, tapi menghafal dengan gerakan dan artinya sangat membantu anak untuk tidak sekedar menghafal tetapi juga memahami Al-Qur'an.

\section{REFERENSI}

Bersama Islam.Lima bersaudara Ini Hafal Quran dengan Metode Unik http://digilib.iainkendari.ac.id/786/3/BAB\%20II.pdf

https://kbbi.kemdikbud.go.id/entri/metode

Kharis Sulaiman, Hasri, Maryam, 'Studi Perbandingan Kemampuan Menghafal AlQur'an Dengan Metode Kaisa Dan Metode Wafa Dalam Menghafal AlQur'anpada Anak Usia Dasar Di Rumah Tadabbur Qur'an (Rtq) Kendari', Tadarus: Jurnal Pendidikan Islam, 8 (2019)

Salamah, Umi, 'Pengajaran Menggunakan Metode Kaisa Dalam Menghafal AlQur'an Pada Anak', TA'LIMUNA, 7 (2018), 124-28

Setiawan, Eko, 'Meningkatkan Kemampuan Membaca Awal Al-Qur'an Melalui Metode Albana Pada Anak Usia 5-6 Tahun', AL-MUDARRIS: Journal of Education, 1 (2018), 68-75 <https://doi.org/10.32478/al-mudarris.v1i2.170> 